\title{
ОСОБЛИВОСТІ ПСИХОЕМОЦІЙНИХ І КОГНІТИВНИХ ПОРУШЕНЬ У ХВОРИХ НА ЦУКРОВИЙ ДІАБЕТ 2 ТИПУ В ПОЄДНАННІ 3 ДІАБЕТИЧНОЮ СТОПОЮ
}

\author{
C. О. Рак \\ Тернопільський національний медичний університет \\ імені І. Я. Горбачевського МОЗ Украӥни
}

У статті наведено результати аналізу психоемоційних та когнітивних порушень у хворих на цукровий діабет 2 типу, ускладнений діабетичною стопою. Автори відзначають прямо пропорційну залежність між клінічною формою діабетичної стопи та ступенем вираження когнітивних порушень.

\section{PECULIARITIES OF PSYCHOEMOTIONAL AND COGNITIVE DISORDERS IN PATIENTS WITH TYPE 2 DIABETES IN COMBINATION WITH DIABETIC FOOT}

\author{
S. O. Rak
}

\section{Horbachevsky Ternopil National Medical University}

The article presents the results of the analysis of psycho-emotional and cognitive disorders in patients with type 2 diabetes complicated with diabetic foot. The authors note a direct relationship between the clinical form of diabetic foot and the degree of expression of cognitive impairment.

Вступ. Цукровий діабет (ЦД) є однією з найпоширеніших та найбільш ускладнених ендокринних патологій. Роль психічного параметра (стресу) у виникненні цукрового діабету на сьогодні $\epsilon$ доведеною [1].

Поряд із відомими фахівцям явищами астенії, нервової анорексії, дистрофії в структурі психічних порушень при цукровому діабеті останнім часом усе частіше стали відзначати депресії та тривожні розлади різного ступеня вираженості. Проведені дослідження показали, що особливістю для пацієнтів із цукровим діабетом $€$ наявність у клінічній картині іпохондричної фіксації на власних хворобливих переживаннях [2].

У формуванні психічних розладів важливу роль відіграє тип цукрового діабету, його тривалість та ступінь компенсації. Початок хвороби в дитячому і підлітковому віці та тривалий (більше 8-9 років) перебіг захворювання створюють усі передумови для патологічного розвитку особистості хворих [3].

Пацієнти з цукровим діабетом - це люди з хронічним захворюванням, які, здебільшого, можуть гостро реагувати на свою хворобу і лікування. Подібні реакції зумовлені усвідомленням хронічного характеру хво-

(c) C. O. Рак, 2020 роби з тривалими, гострими, прогресуючими ускладненнями та необхідністю постійного лікування [4].

Встановлення діагнозу цукрового діабету $є$ шокуючим для більшості пацієнтів та їхніх рідних. Як наслідок, можуть виникати порушення психоемоційної сфери, що проявляється у вигляді розладів самооцінки, пригнічення, розпачу та депресії [5].

З 1986 р. використовують термін «діабетична особистість». Їй властиві емоційна нестійкість, невротичні реакції, байдужість, тривожність, лабільність настрою. Крім первинних розладів функції нервової системи, при цукровому діабеті мають значення соціально-психологічні фактори (зниження працездатності, щоденні ін'єкції, статева дисфункція), особливості характеру індивідуума (тривожно-недовірливі риси в поєднанні з прямолінійністю, ригідністю психіки), несприятливі зовнішні впливи у формі перенапруження й психічних потрясінь, вплив тривалого медикаментозного лікування [6].

Депресивний психоз із тривогою або без неї - найпоширеніший розлад у хворих на цукровий діабет. Вчені звертають увагу на наявність у осіб із цукровим діабетом депресій. Безліч авторів згадують про те, що 
вони спостерігають депресивні стани переважно на початку захворювання [7].

У літературі трапляються окремі описи депресії у хворих на цукровий діабет, що виникають при тяжкому перебігу ендокринного захворювання, що супроводжується частими комами.

Основна частина. У 59 пацієнтів із ЦД 2 типу за допомогою шкали Mini Mental State Examination (MMSE) обстежено когнітивну сферу. Серед обстежених було 32 жінки (54,24\%) та 27 чоловіків (45,76 \%). Аналізуючи отримані результати, у 10 осіб (16,9\%) не виявлено порушення когнітивних функцій, у 43 пацієнтів (72,9\%) виявили когнітивні порушення та в 6 хворих (10,2%) була наявна деменція легкого ступеня вираженості. Середній бал за шкалою MMSE у досліджуваній групі

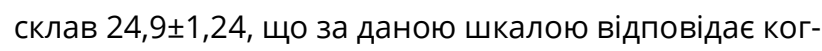
нітивним порушенням (КП).

Усі обстежені пацієнти, які хворіли на цукровий діабет в поєднанні з діабетичною стопою, за віковою категорією та гендерними особливостями поділені на 2 підгрупи: 1 підгрупа - 25 пацієнтів віком 45-59 років, 2 підгрупа - 34 хворих віком 60 років і старші (табл. 1).
Встановлено, що в 1 підгрупі когнітивні порушення спостерігали відносно частіше серед жінок, що склало $57,1 \%$, у той час, як серед чоловіків КП діагностували в 45,5 \% у відповідній віковій підгрупі (p<0,05).

Якщо ж аналізувати 2 підгрупу пацієнтів із ЦД 2 типу в поєднанні з діабетичною стопою, помічено, що частота когнітивних порушень була більш вираженою у чоловіків і склала 83,3 \%, при цьому в 61,1 \% були наявні помірні когнітивні порушення, а в 22,2 \% - виявлено деменцію легкого ступеня. Отже, виходячи з вищевказаних даних, можна говорити про те, що в 1 підгрупі хворих віком 45-59 років КП виявлено у $52 \%$, а в 2 підгрупі пацієнтів із ЦД 2 типу у віковому діапазоні 60 років і старші КП виявлено в 76,5 \% від загальної кількості обстежуваних, при цьому в 23 \% з них діагностовано деменцію легкого ступеня вираженості за допомогою шкали MMSE.

Порівнюючи дві вікові категорії та оцінюючи результати дослідження, можна говорити про те, що КП частіше спостерігають у більш зрілому віці та більш виражені були в жінок у віковій категорії 60 і старші, ніж у чоловіків ( $p<0,05)$.

Таблиця 1. Частота когнітивних порушень у хворих на цукровий діабет 2 типу згідно з віковою категорією та гендерними особливостями

\begin{tabular}{|c|c|c|c|c|}
\hline \multirow{2}{*}{$\begin{array}{c}\text { Вік, } \\
\text { загальна кількість } \\
\text { хворих }\end{array}$} & \multirow[b]{2}{*}{ Кількість хворих, стать } & \multicolumn{3}{|c|}{ Когнітивні порушення } \\
\hline & & немає порушень & $\begin{array}{c}\text { наявні когнітивні } \\
\text { порушення }\end{array}$ & $\begin{array}{c}\text { деменція легкого } \\
\text { ступеня }\end{array}$ \\
\hline \multirow{2}{*}{$\begin{array}{l}\text { 45-59 років, } \\
25 \text { пацієнтів }\end{array}$} & 11 чоловіків (44 \%) & $1(9,1 \%)$ & $10(90,9 \%)$ & - \\
\hline & 14 жінок (56 \%) & $2(14,3 \%)$ & $12(85,7 \%)$ & - \\
\hline \multirow{2}{*}{$\begin{array}{l}60 \text { років і старші, } \\
34 \text { пацієнта }\end{array}$} & 16 жінок (47,1 \%) & $1(6,3 \%)$ & $13(81,3 \%)$ & $2(12,4 \%)$ \\
\hline & 18 чоловіків (52,9%) & $6(33,3 \%)$ & $8(44,4 \%)$ & $4(22,3 \%)$ \\
\hline
\end{tabular}

Варто відзначити, що у хворих на ЦД 2 типу в поєднанні з діабетичною стопою тривалість захворювання впливала на прояви когнітивних порушень.

Залежно від тривалості захворювання на цукровий діабет та гендерної належності ми поділили групу пацієнтів із ЦД 2 типу на 2 підгрупи. В 1 підгрупу, з тривалістю захворювання до 10 років, увійшов 21 хворий, серед яких кількість жінок склала 11 осіб (52,4 \%) та 10 чоловіків (47,6 \%). У 2 підгрупі, з тривалістю захворювання на ЦД 2 типу від 11 років, обстежено 38 хворих, з яких кількість чоловіків була 17 (44,7 \%) і, відповідно, кількість жінок склала 21 особа (55,3%) (табл. 2).

Аналізуючи дані когнітивної сфери пацієнтів із ЦД 2 типу залежно від статі та тривалості захворювання, когнітивні порушення були наявні приблизно в однаковій відсотковій кількості як у чоловіків, так і в жінок,

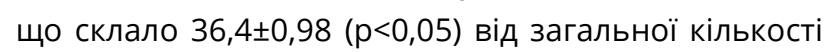

пацієнтів у досліджуваній підгрупі з тривалістю захворювання до 10 років.

Вивчаючи результати 2 підгрупи, можна говорити про те, що ризик розвитку КП у пацієнтів із ЦД 2 типу в поєднанні з діабетичною стопою збільшується пропорційно зі збільшенням тривалості захворювання.

Залежно від наявної клінічної форми діабетичної стопи, усіх пацієнтів із ЦД 2 типу поділено на 3 підгрупи. До 1 підгрупи з нейропатично-інфікованою формою діабетичної стопи увійшло 20 пацієнтів (33,9 \%), 2 підгрупу склали пацієнти 3 ішемічногангренозною формою - 24 пацієнти (40,7 \%) і до 3 підгрупи зі змішаною формою віднесено 15 осіб $(25,4$ \%) (табл. 3).

Проаналізувавши наявність КП у пацієнтів із ЦД 2 типу залежно від клінічної форми діабетичної стопи, виявлено, що від когнітивної дисфункції у 1 підгрупі страждає 40 \%, у 2 підгрупі хворих із КП було 75 \%, а

56 ISSN 2411-1597. МЕДСЕСТРИНСТВО. 2020. № 1 
Таблиця 2. Когнітивні розлади у пацієнтів із цукровим діабетом 2 типу залежно від статі та тривалості захворювання

\begin{tabular}{|c|c|c|c|c|}
\hline \multirow{2}{*}{$\begin{array}{c}\text { Тривалість захво- } \\
\text { рювання, загальна } \\
\text { кількість хворих }\end{array}$} & \multirow{2}{*}{$\begin{array}{c}\text { Кількість хворих, } \\
\text { стать }\end{array}$} & \multicolumn{3}{|c|}{ Когнітивні порушення } \\
\hline & & немає порушень & $\begin{array}{c}\text { наявні когнітивні } \\
\text { порушення } \\
\end{array}$ & $\begin{array}{c}\text { деменція легкого } \\
\text { ступеня }\end{array}$ \\
\hline \multirow{2}{*}{$\begin{array}{l}\text { До } 10 \text { років, } \\
21 \text { (35,6 \%) }\end{array}$} & 10 чоловіків (47,6 \%) & $6(60,0 \%)$ & $4(40,0 \%)$ & - \\
\hline & 11 жінок $(52,4 \%)$ & $7(63,6 \%)$ & $4(36,3 \%)$ & - \\
\hline \multirow{2}{*}{$\begin{array}{l}\text { Від } 11 \text { років, } \\
38(64,4 \%)\end{array}$} & 17 чоловіків (44,7 \%) & $4(23,5 \%)$ & $13(76,5 \%)$ & - \\
\hline & 21 жінка $(55,3 \%)$ & $2(9,5 \%)$ & $15(71,4 \%)$ & $4(19,1 \%)$ \\
\hline
\end{tabular}

Таблиця 3. Когнітивні порушення у хворих на цукровий діабет 2 типу залежно від клінічної форми діабетичної стопи

\begin{tabular}{|l|c|c|c|}
\hline $\begin{array}{c}\text { Клінічна стадія } \\
\text { діабетичної стопи }\end{array}$ & $\begin{array}{c}\text { Кількість хворих } \\
\text { у підгрупі }\end{array}$ & $\begin{array}{c}\text { Кількість хворих без } \\
\text { когнітивних порушень }\end{array}$ & $\begin{array}{c}\text { Кількість хворих з когнітивними } \\
\text { порушеннями }\end{array}$ \\
\hline 1 стадія & $20(33,9 \%)$ & $12(60 \%)$ & $8(40 \%)$ \\
\hline 2 стадія & $24(40,7 \%)$ & $6(25 \%)$ & $18(75 \%)$ \\
\hline 3 стадія & $15(25,4 \%)$ & $2(13,3 \%)$ & $13(86,7 \%)$ \\
\hline
\end{tabular}

найвираженіші КП спостерігали в 3 підгрупі обстежених пацієнтів, що становило 86,7\%.

Висновки. Найвищий показник когнітивних порушень спостерігали у групі пацієнтів, які страждали від цукрового діабету в поєднанні зі змішаною формою діабетичної стопи, і він становив 86,7 \%.

\section{СПИСОК ЛІТЕРАТУРИ}

1. Мокрій В. Я. Особливості формування окисного стресу у хворих на цукровий діабет 2-го типу залежно від тривалості захворювання та статі / В. Я. Мокрій, С. В. Зябліцев, М.В.Кришталь // Міжнародний ендокринологічний журнал. - 2016. - № 5. - С. 67-71.

2. Радченко О. М. Особливості перебігу цукрового діабету при різних типах загальних неспецифічних адаптаційних реакцій / О. М. Радченко, О. Я. Королюк, М. В. Сироїд // Галицький лікарський вісник. - 2003. № 3. - С. 68-71.

3. Мокрий В. Я. Порушення системи перекисного окиснення ліпідів при цукровому діабеті 2-го типу (огляд літератури) / В. Я. Мокрий, С. В. Зябліцев, Р. М. Борис // Міжнародний ендокринологічний журнал. - 2015. - № 7. - C. 41-44.

4. Павловський М. П. Вплив олії амаранту, насиченої синглетним киснем, на характер загальних адаптаційних реакцій у хворих із синдромом діабетичної стопи /
Ризик розвитку КП пропорційно збільшувався зі збільшенням тривалості захворювання.

Когнітивні порушення частіше виявляли у віковій категорії 60 років та старші, причому більш серйозні прояви спостерігали у чоловіків, ніж у жінок.

М. П. Павловський, В. С. Заремба, Ю. А. Котик // Фітотерапія. - 2007. - № 3. - С. 3-9.

5. Мельник В. С. Взаємозв'язок між стресовою гіперглікемією та віддаленими наслідками гострого ішемічного інсульту / В. С. Мельник // Український медичний часопис. - 2006. - № 1. - С. 100-103.

6. Жердьова Н. М. Взаємозв'язок між периферичною діабетичною нейропатією та когнітивними порушеннями у пацієнтів на цукровий діабет 2 типу зрілого віку / Н. М. Жердьова, Б. М. Маньковський // 3б. наук. пр. співробітників НМАПО ім. П. Л. Шупика. - 2017. - Вип. 27. C. 245-252.

7. The reaction of the neuroendocrine hypothalamus on intermittent hypoxia in rats with streptozotocine-induced diabetes / Yu. M. Kolesnik, E. V. Kadzharyan, A. V. Abramov, O. V. Melnikova // Клінічна фармація. - 2013. - 17, № 4. C. 41-44. 